\title{
CYP11B2 Gene
}

National Cancer Institute

\section{Source}

National Cancer Institute. CYP11B2 Gene. NCI Thesaurus. Code C40062.

This gene is involved in mineralocorticoid metabolism. 